\title{
On the political economy and limits of crisis insurance: the case of the 2008-11 bailouts
}

\author{
Roger D. Congleton
}

Received: 4 November 2011 / Accepted: 5 November 2011 / Published online: 1 December 2011

(C) Springer Science+Business Media, LLC 2011

\begin{abstract}
The bailouts of 2008-10 are the most recent in a long series of insurance-like policies designed to limit the losses of those harmed by a crisis of some kind-but enacted after a crisis is under way.

This paper analyzes the economics and politics of "crisis insurance" programs. The analysis helps explain why ex-post insurance is popular, why it tends to be undersupplied by private markets, and why governments may be better able to provide it. The analysis also points out that there are limits to what losses can be covered. The routine adoption of new programs to limit losses from crises tends to require greater expenditures through time because of moral hazard problems and the nature of crises. Eventually, this trend may produce "uninsurable" crises.

The analysis of this paper suggests that such problems can be moderated, although not eliminated, through appropriate standing polices for ex-post funding of crisis insurance.
\end{abstract}

Keywords Crisis insurance $\cdot$ Financial crisis $\cdot$ Political economy $\cdot$ Public choice $\cdot$ Crisis management · Rainy day funds · Government debt · International borrowing limits

\section{Introduction: government bailouts as crisis insurance}

A crisis is nearly always a surprise, but that is not to say that a crisis is totally unexpected. As a crisis approaches, policymakers normally hear many warnings, but the warnings are ignored. This is not because the men and women occupying positions of authority are necessarily careless or stupid, but because so many warnings are. Which warnings to take seriously cannot be known without giving them some time and attention, both of which are scarce resources. Because most warnings prove to be false alarms, policymakers quite sensibly neglect most warnings, so that they can focus on problems where the benefits of planning and management seem to be higher. Such rational neglect may be reinforced by the

R.D. Congleton $(\bowtie)$

Department of Economics, West Virginia University, Room 405, B\&E blg., Morgantown, WV 2505,

USA

e-mail: roger.congleton@mail.wvu.edu 
natural temptation to ignore warnings that suggest that one's past policies were mistaken. Nonetheless, some neglected warnings are true, and many crises could have been avoided or ameliorated by taking them seriously.

Once underway, all crises require rapid responses to the problems at hand. Crises nearly always imply that sudden substantial reductions in health or wealth are likely under existing policies. Policymakers thus often conclude that old plans need to be revised and/or new policies adopted, more or less immediately, to reduce or avoid those losses. Unfortunately, the greater the crisis, the greater the losses threatened, and the less likely it is that all the losses can be avoided through such changes.

Those threatened or damaged often lobby governments for various forms of bailoutsthat is to say, for taxpayer-financed programs that limit the losses associated with the crisis at hand. Such programs are similar to insurance in that only those damaged are eligible for program benefits, but differ from ordinary insurance in several ways, as developed in this paper. Although some groups are more effective at gaining "ex-post insurance" programs than others, a broad range of loss-limiting programs are routinely provided by democratic governments after unusually bad weather, earthquakes, epidemics, and economic crises.

The financial crisis of 2008 was a case in point. There were many warnings, most were ignored, and so a variety of microeconomic and macroeconomic steps that might have headed off or reduced the financial crisis were not taken, nor were plans for dealing with the crisis that emerged much developed. ${ }^{1}$ As a series of unpleasant surprises unfolded, new strategies had to be devised without careful analysis or review. In the end, a broad range of persons and organizations throughout the world were damaged by the crisis as assets were re-priced and jobs were lost. An organized subset of the damaged firms and individuals lobbied for new forms of crisis insurance. The success of these lobbying efforts caused existing safety net programs to be extended and new ones to be created. Some were created through routine legislation. Others were created through reinterpretations of existing statutory authority.

This paper examines the logic and consequences of crisis insurance, why some losses cannot be insured privately, why governments may fill the breech, and why governments are ultimately limited in their ability to do so. The analysis suggests that crisis insurance is a type of insurance that private markets under-provide, even though there is broad demand for such financial instruments. Governments can provide such insurance more effectively than the private sector, because of their greater borrowing ability and because they can force "subscribers" to pay for the insurance after the fact in a manner that private insurance companies cannot. The events associated with the 2008 financial crisis are used to illustrate and support the theory.

Section 2 provides microeconomic foundations for the demand for publicly funded crisis insurance. Section 3 provides a short overview of the financial crisis of 2008-11. It is largely a condensed and updated version of Congleton (2009) and the Financial Crisis Inquiry Commission's Report (2011), but places greater emphasis on surprise and inadequate reserves. Sections 4 and 5 provide overviews of the expanded safety net programs adopted in the United States in response to the 2008 crisis and the recession induced by it. Relatively few of these programs have attracted much press attention, although several of them are extraordinarily large. Section 6 concludes the paper by analyzing the limits of a government's ability to price and provide ex-post social insurance.

\footnotetext{
${ }^{1}$ The Financial Crisis Inquiry Commission (2011) argues that the financial crisis was in principle avoidable and reports that many warnings were raised and ignored: "The captains of finance and the public stewards of our financial system ignored warnings and failed to question, understand, and manage evolving risks within a system essential to the well-being of the American public. Theirs was a big miss, not a stumble. While the business cycle cannot be repealed, a crisis of this magnitude need not have occurred" (pg. xvii).
} 
The analysis suggests that crisis insurance cannot limit all losses and that the upper bound of coverage is more likely to be reached when crisis insurance is underpriced. The bailouts of 2008-11 appear to bring us close to the economic and political limits of such programs.

\section{The domain of crises and the demand for crisis insurance}

A few ideas from information theory and statistics can be used to analyze the possibility of unpleasant surprises and the limits of both ordinary insurance and crisis insurance. Crises are normally created by unpleasant surprises that call for immediate, unanticipated changes in plans. Such surprises may arise in three settings. In some cases, the possible range of outcomes and probabilities of those outcomes are known, but some of the outcomes are considered so unlikely that they are not given serious attention. In other cases, surprises occur because the world is so complicated that some events cannot be assigned meaningful probabilities with the data available. In both cases, even a series of fairly common events can be surprising, because the likelihood of the series has been under-assessed. Moreover, the variety of possible events may be so broad that some possibilities are unknown or unimagined, because they have never been experienced. The building in which "you" are reading this article may begin collapsing from an exceptionally strong gust of wind, a subtle series of construction defects, or from an event never previously considered or perhaps even imagined, a meteor strike.

Knowing that unpleasant surprises have occurred in the past allows one to anticipate that unpleasant surprises will occur in the future, although complete plans for dealing with them cannot be worked out beforehand, because the exact nature of the surprise cannot be known before it happens. Fortunately, a variety of steps can reduce the losses from a broad variety of unpleasant surprises and their associated crises. For example, the ability to respond to unpleasant surprises is nearly always enhanced by the existence of readily available pools of resources that can be used to address a crisis and its consequences.

\subsection{Rainy day funds, emergency loans, and bailouts as crisis insurance}

Such emergency reserves or "rainy day" funds resemble conventional insurance funds, but differ in significant ways. Conventional insurance programs create funds that are in effect shared among subscribers for a price based on average payouts and their variation through time. For surprise events, such calculations are not possible. The event space and its associated losses may not be fully understood, or the range of losses generated may be too large for robust funds covering all losses to be accumulated. Emergency reserves are thus far much more likely to be too small than ordinary insurance funds. This difference is partly what Frank Knight (1921) had in mind in his classic analysis of risk and uncertainty, although he focused on profits, rather than losses.

The difference between the losses covered by ordinary insurance and emergency reserves can be illustrated by contrasting uniform with normal distributions of losses. Within a uniform distribution, complete insurance for any finite number of worse case outcomes is possible, because there is a lowest possible payoff. Within a normal distribution of losses, however, such reserves are impossible, because the greatest possible loss is unbounded. Thus, every finite rainy day fund that attempts to cover losses from a normally distributed loss generating process confronts a positive probability that a loss that will completely exhaust the fund. A rainy day fund can be designed to cover $99 \%$ of the possible loss scenarios, but 
not all of them, whenever the losses are generated by any unbounded stochastic or chaotic process.

Insurers recognize that they cannot accumulate sufficient funds to cover damages from all possible combinations of emergencies and/or sell such insurance at a reasonable price. In cases in which very large losses are possible, insurance companies normally cover losses only up to a predetermined maximum, and often insure only a subset of the events known to be possible. For example, home insurance policies have a maximum payout and routinely exclude losses from floods and revolutions (for which multiple, very large, simultaneous claims are likely). Similarly, liability insurance normally is sold with a maximal judgment for a single claim and maximal total for simultaneous claims.

To routinely insure against rare but very high loss events would cause every insurance company to fail in the long run, even though profits may be realized in the period before the disastrous events occur.

As a consequence, individuals and organizations have to self-insure for a broad range of day to day emergencies. They do so for the most part by establishing rainy day funds, which often include lines of credit. The rainy day funds of consumers, firms, and governments can be used to cover a broader range of emergencies than ordinary insurance, because they are not event-specific and can be quickly used to address a broad range of problems. Coverage from private rainy day funds also has limits. However, these are not determined by contract, as the case for ordinary insurance, but by the size of the funds (and any associated lines of credit).

When losses from catastrophic events exhaust private insurance and private rainy day funds, the affected groups will attempt to secure additional resources through other means. For example they may lobby government decisionmakers for loans at below market interest rates or for direct payments and services, which limit their losses for the crisis at hand.

Such governmental crisis insurance programs are widely supported for both pragmatic and altruistic reasons. Affected voters (and interest groups) have obvious reasons to favor programs that reduce their losses, especially subsidized programs. However, the damaged groups are rarely sufficiently large that new programs can be adopted without support from unaffected voters. Unaffected voters often also favor the extension of crisis insurance. Many voters are risk averse and willing to pay for supplemental, nonspecific, crisis insurance; because they may need it themselves during the next crisis. Altruism may also play a role as evidenced by the broad private and public support for victims of domestic and international disasters.

Most democratic governments have gradually increased the scope of standing programs for providing crisis insurance. Their central government provides increasingly generous flood insurance, unemployment insurance, bank deposits insurance, and many other insurance-like programs. Such standing programs resemble ordinary insurance programs during ordinary times, insofar as they are largely prefunded with earmarked fees and taxes during such times. They differ in that during unusually unfortunate times their coverage is normally extended beyond that provided by prefunded reserves. For example, between 1993 and 2001, flood insurance payouts exceeded revenues by $\$ 843$ million (GAO 2001: 2). Similarly, the damages to residents of New Orleans caused by Hurricane Katrina in 2005 were not paid entirely from preexisting funds. Flood insurance reserves were augmented, and a 
Fig. 1 Losses covered by Federal Flood Insurance (millions of 1982 dollars)

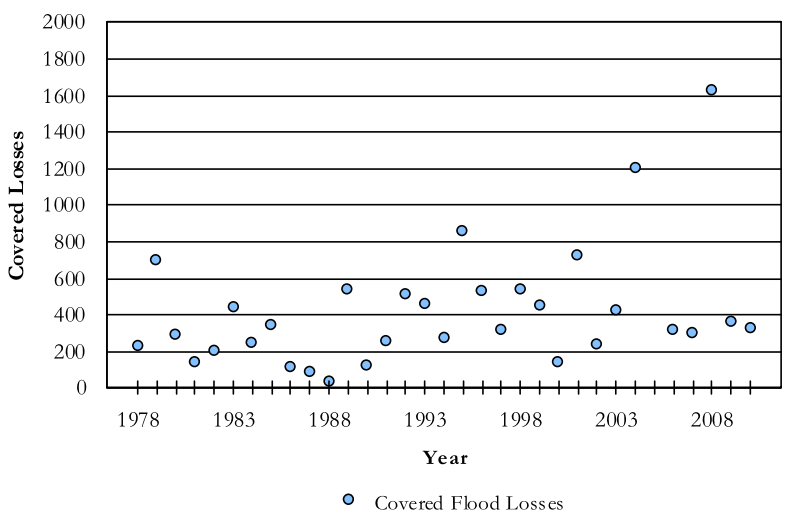

variety of new "bailout programs" were created. ${ }^{2}$ In the long run, a succession of crises tends to gradually expand the domain of government. ${ }^{3}$

\subsection{Crisis insurance and moral hazard}

In many respects, government programs that address emergencies are similar to ordinary insurance programs. For example, only those directly harmed by a crisis are normally eligible for the programs of interest. In many cases, the payments to persons and organizations are formally limited, as with weeks of unemployment insurance benefits or maximum amounts covered by deposit insurance. In contrast to the private sector, however, the government normally expands coverage during a crisis (because of popular or interest group demands) by borrowing, printing money, or imposing ex-post fees for the new coverage. That is, the "limits" are not binding in the manner of private insurance. Government crisis insurance programs also tend to be relatively large, because all but large crises can be addressed through private insurance and rainy day funds.

When funded through general revenues, crisis insurance tends to under-price risk (and uncertainty), because risks are not likely to be proportional to the tax payments of individual taxpayers.

When crisis risk is not properly priced and people anticipate the routine extension of crisis insurance, moral hazards tend to increase, and payouts from crisis insurance programs tend to grow through time. In general, the underpricing of "bailouts" tends to encourage smaller private rainy day funds, smaller purchases of private insurance, and also somewhat more risky behavior. Guaranteeing the securities of financial institutions tends to encourage imprudent risk taking. Subsidized flood insurance encourages more expensive and frail houses to be built on river flood plans and along sea coasts. Note, for example, in Fig. 1 the

\footnotetext{
${ }^{2}$ Flood insurance is mandated if a project is supported by government grants or loans are to be eligible for purchase by federal agencies. The latter program is to reduce risk for lenders and agencies holding the mortgages. Other insurance can be purchased voluntarily from the program. Additional program and financial information can be found in (GAO 2001). Voluntary subscription to flood insurance beyond that mandated is less than one might have anticipated, given the subsidies. Young (2008) discusses how the flood insurance program was overwhelmed by Katrina losses. Brown and Hoyt (2000) analyze the demand for flood insurance in general. Emergency legislation that provided new or extended safety nets after hurricane Katrina is discussed in Congleton (2006).

${ }^{3}$ A similar point is made in Higgs (1989), but from a somewhat different perspective.
} 
upper payouts from flood insurance in the U.S. have tended to grow through time in periods of unusually high water.

Such moral hazard problems tend to be larger for crisis insurance programs than for ordinary insurance, because it is difficult to price risks associated with rare and unexpected events both before and after they occur. Indeed, the above analysis implies that it is essentially impossible to price crisis insurance before a specific crisis emerges.

\section{A short recapitulation of the financial surprises of $\mathbf{2 0 0 8}$}

Responses to the 2008 financial crisis and its aftermath provide very useful evidence about the nature of government responses to a very large crisis, and also about the ultimate limits to such responses.

For the past century, democratic governments have increasingly taken on the responsibility to insure a broad range of losses associated with economic crises, as with deposit insurance, unemployment insurance, and much of macroeconomic policy. Governmental responses to the 2008 financial crisis were not unique, although they were tailored for the problems associated with it. The financial crisis of 2008 and the associated extension of expost insurance differed from other recent financial crises in the United States, such as the savings and loan (S\&L) crisis of the late 1980s and early 1990s, mainly in their magnitudes.

In this case, the crisis was not caused by ignorance of possibilities, because it was well known that real estate and other asset values both rise and fall. It was also well known that risks can be over or under priced. Rather, it was a problem of outliers. Possibilities that had been thought sufficiently unlikely to be ignored came to pass.

The financial crisis of 2008 was largely the consequence of the systematic under-pricing of risk and insurance in private markets. A broad cross-section of consumers, firms, and governments maintained reserves (rainy day funds) that were too small to cope with sudden reductions in their cash flows, incomes, and wealth. Within the financial sector, firms that thought they were selling or purchasing ordinary insurance found out to their surprise that they were actually providing or acquiring private crisis insurance. Reserves that had been adequate for "normal" variations in the relevant insurance claims in the previous decade were not sufficient for larger ones experienced as the housing bubble burst.

Because risks were underpriced, a variety of assets were overpriced. The most important overpriced asset was housing, which had been rising rapidly in value for more than a decade.

\subsection{The end of the housing bubble}

As long as housing prices rose, the asset values of the houses supporting mortgages were sufficient (indeed more than sufficient) to support a variety of risky loans in the consumer, commerce, and finance sectors of the economy. The steady increase in house prices allowed highly leveraged house "owners" to refinance to address any short-term cash flow problems that emerged. It also allowed relatively high profits for home-owner speculators, loan originators, mortgage bundlers and mortgage insurers such as Fannie Mae and Freddie Mac.

In 2006 housing prices in the United States and several other countries began to fall for the first time in more than a decade and fell far more rapidly than in any period during the previous half century. The 2006-09 decline was the first significant reduction in house prices since the recession of 1992, and the decline was much greater and faster than in that relatively mild recession. According to the Case-Shiller index, seasonally adjusted house 


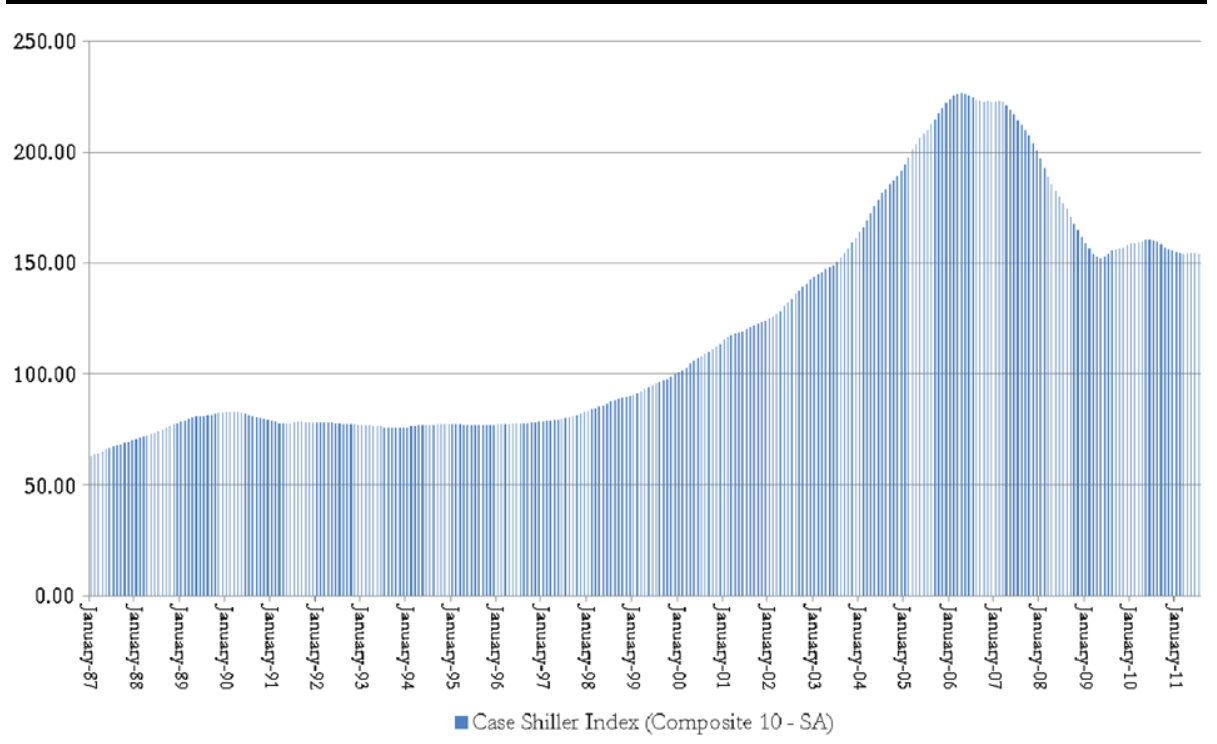

Fig. 2 Case Shiller index of U.S. housing prices (composite 10-SA) 1987-2011

prices in the 1992 recession peaked in March 1990 (at 82.73) and fell by about 6\% by April 1991 (to 77.45). Housing prices did not return to their 1990 high until December 1997 (82.59). In contrast, seasonally adjusted housing prices in 2006-09 peaked in May 2006 (at 226.63) and fell five times farther, by about $32 \%$, during the next three years (to 152.23 in May 2009). ${ }^{4}$ Two years later (in May 2011) the index remained at more or less the same level (154.42). The U.S. Census series on median home prices peaked in 2007 and shows a similar broad decline in home prices during 2007-10.

Diversifying across regions of the country could not reduce this risk, because average house values fell throughout the United States. (Indeed, a few real estate bubbles also "burst" in other countries at about the same time.)

Although explanations for the existence and piercing of asset-price bubbles vary (Capozza and Seguin 1994; Lei et al. 2001), there is little disagreement among economists that the end of such bubbles can have real effects on other markets. For example, Case et al. (2001) find that stock market and real estate price fluctuations have significant effects on household consumption levels, with the effects of housing price declines being larger than those from stock price declines. Cecchetti (2008) reports that housing booms reduce growth prospects, although equity booms have little impact on macroeconomic performance. The $32 \%$ decline in U.S. home values between 2006 and 2009 reduced homeowner wealth (equity) by about $\$ 6$ trillion. ${ }^{5}$

\footnotetext{
${ }^{4}$ The monthly and quarterly Case-Shiller indices differ somewhat and the index itself has evidently been revised in the past few years. Earlier quarterly index values show a much smaller decline in housing prices in 1990-92 and a more rapid recovery. The data used above are monthly, seasonally adjusted values, downloaded from Standard and Poor's in September 2011. The more recent numbers remain of the same order of magnitude as in earlier quarterly releases.

${ }^{5}$ According to the Kennickell (2006, Table 11a) the value of (net) equity in personal homes in 2006 was $\$ 19.1$ trillion.
} 


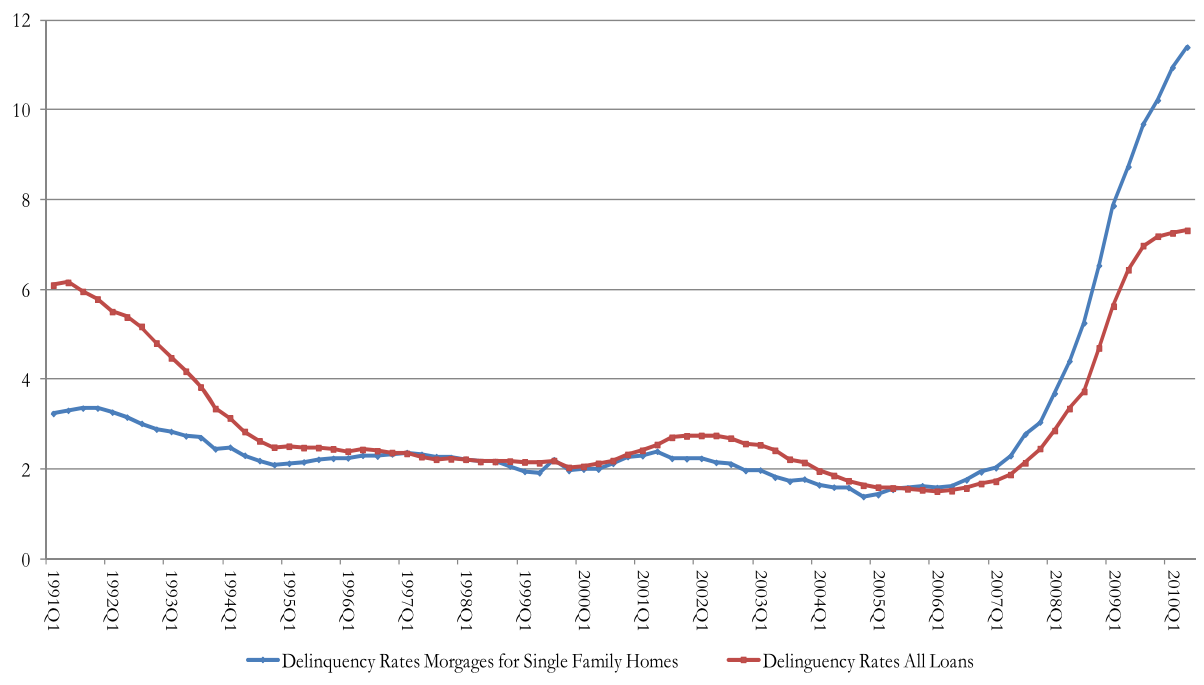

Fig. 3 Delinquency rates at all commercial banks 1991-2010 (quarterly, seasonally adjusted, FRB)

\subsection{The end of "risk-free" mortgage-backed securities}

The unprecedented magnitude of the housing price decline, see Fig. 2, together with increasing unemployment, had major effects on important financial markets worldwide, because so many mortgages and other loans had been securitized during the previous two decades. Many real estate owners were completely leveraged and so were unable to refinance to meet their short-term cash-flow problems and thereby pay their mortgages.

Before 2006, mortgages and mortgage-backed securities were regarded to be low risk assets, because delinquencies tended to be below those of other loans. Delinquencies on residential mortgages had been moderate in the period after the 1992 recession and, if anything, exhibited a slight downward trend through 2005. Moreover, the purchasers of mortgagebacked securities had been assured that their mortgage-backed securities were both properly diversified and insured by the "independent" risk assessments of Fitch's, Moody's, and Standard and Poor's. ${ }^{6}$ Consequently, mortgage-backed securities played an important role as "safe assets" in many large investment portfolios and reserve funds, including those of financial firms, sovereign wealth funds, and pension funds.

Mortgage delinquencies began to rise to unprecedented levels in 2006, see Fig. 3, and sub-prime mortgages were disproportionately represented among delinquencies. Delinquencies on residential real estate loans had more than doubled by the beginning of 2008 . They doubled again by the beginning of 2009, climbing to rates not seen in the post-World War II period. Nearly $25 \%$ of sub-prime mortgages were 90 days delinquent or in foreclosure at the end of 2008 (Duke 2009). ${ }^{7}$

\footnotetext{
${ }^{6}$ The assumption that housing-backed securities were low risk did not require all housing markets to have sustained trends, but it did assume that housing market prices were uncorrelated and generally trended upward. Both assumptions proved incorrect.

${ }^{7}$ Bernanke's (May 5, 2008) Figs. 1 and 2 demonstrate that delinquency rates vary widely across the country. Prior to the crisis, in 2004, these ranged from $0.6 \%$ in the lowest quintile to more than $2.5 \%$ in the highest quintile. During 2004-07, delinquencies rose in many parts of the Southwest, Southeast, and Midwest, while relatively few delinquencies occurred in most parts of the Northwest. Fed board of governors member Duke's
} 
As delinquency rates began to exceed the normal range of the post-1992 period, mortgage insurance claims began to increase, which required mortgage and mortgage-backed securities insurers to pay the interest payments that delinquent borrowers were not making. ${ }^{8}$ In difficult times, insurance is only as good as an insurance company's net cash flow, portfolio of reserves, and line of credit. Unfortunately, but perhaps predictably, insufficient reserves had been maintained by those insuring mortgages and mortgage-backed securities, because they had evidently assumed that the benevolent national trends between 1995 and 2005 were the new market norm. As delinquencies increased, mortgage insurers began to pay out more than they were taking in fees and interest. Losses accumulated as payments to those insured exceeded payments from those holding the mortgages.

As neglected outlier possibilities came to pass, insurer losses accumulated, and the stock prices of insurers naturally fell, which meant that they could not raise new money to make their "guaranteed payments" to mortgage-backed security holders by selling stock or borrowing. Private mortgage insurance began to disappear. Several large private insurers of mortgage-backed securities filed for bankruptcy protection in 2007. New Century Financial Corporation filed for bankruptcy in April, Countrywide Financial Corporation in July, and American Home Mortgage Investment Corporation in August. Several other major financial institutions approached bankruptcy, as their insurance-like obligations exceeded their reserves (Fannie Mae, Freddie Mac, American International Group [AIG], Bear Sterns, etc.).

This was not simply a cash flow problem that could be solved with a bit of temporary borrowing or a Federal Reserve easing of credit. There were $\$ 10.4$ trillion of outstanding mortgages on one-to-four-family homes in 2006, of which $\$ 7$ trillion worth were held in mortgage pools and trusts supporting mortgage-backed securities (Board of Governors of the Federal Reserve System 2008, p. 33). The decline in real estate prices reduced the supply of credit through effects on the non-bank financial sector reserves, at the same time that demand for cash-flow smoothing loans (supplemental rainy day funds) was increasing. ${ }^{9}$

By 2007 a subset of financial traders had begun to bet against mortgage-backed securities and financial firms with large holdings of mortgage-backed securities (MBSs) by selling short in as many ways as possible (Lewis 2010). This accelerated the collapse of the capital "reserves" of firms holding mortgage and other credit backed securities, because the stock value of companies is normally counted as part of their capital by the SEC. Other firms, however, such as Bear Stearns and Lehman Brothers, continued to believe that MBSs and other real estate securities were attractive investments. ${ }^{10}$

As with tsunamis, the wave of failures initially looked smaller than it would become. A few ripples became a great tidal wave of failures. As mortgage-insurance firms failed,

speech (February 11, 2009) provides a variety of unpublished figures on delinquent mortgages, housing sales, and financing.

${ }^{8}$ The St. Louis Federal Reserve Bank's "Financial Crisis Timeline" notes that in June 2007 Standard and Poor's and Moody's Investor Services downgraded more than 100 bonds backed by second lien sub-prime mortgages. A month later, more than 600 securities backed by sub-prime residential mortgages were placed on a credit watch (www.stlouisfed.org/timeline/timeline.cfm). See also Jenkinson (2008), who provides additional detail about the large downward revisions of "structured" securities by rating agencies in 2007 (by more than one rating category).

${ }^{9}$ The value of the mortgage-backed securities supported by mortgage pools would have initially exceeded the value of the mortgages themselves, because of the lower risk premiums paid for securitized mortgages than for the mortgages themselves (Congleton 2009). A variety of composite securities (CDOs) and various futures markets also existed, which tended to have similar (or worse) responses to increases in mortgage delinquency rates, and also involved commitments that were larger than the pool of mortgages upon which they were grounded (Lewis 2010).

${ }^{10}$ See, for example, Tibman (2009: 86, 120-36), Lewis (2010: 194-213), Greenberg (2010: 136-43). 
the risk of all grades of mortgaged-backed securities was reassessed, and the balance sheets (capital reserves) of investment banks, pension funds, and many local governments imploded like a pricked balloon. ${ }^{11}$

Newspapers, insider accounts, and government agency reports place the lost market value of mortgage-backed securities at between $60 \%-100 \%$, depending on the type of security, which if true, implies that on the order of $\$ 5$ trillion of wealth disappeared from the world's financial system from that one market alone. These losses were about the same magnitude as the reduction in homeowner equity, but they had larger effects on the real economy, because they were concentrated in a very important sector, rather than spread out among households. To put those numbers in perspective, the entire outstanding publicly held debt of the U.S. government was about \$4.25 trillion in 2007 (excluding Federal Reserve holdings). The losses were greater than would be associated with a U.S. default on all of its publicly held debt. $^{12}$

When cash flows were disrupted, the reserves of financial institutions were rapidly depleted, because of the specific form of the 2008 crisis. Using short-term loans to supplement private reserves was not possible. As a consequence, contractual obligations to cover a variety of financial losses could not be met, bankruptcies ensued, and a broad range of financial assets had to be re-priced to reflect both new assessments of risk and the lack of insurance coverage. Similar problems occurred for a broad cross-section of household and nonfinancial firms. The worldwide integration of capital markets in this case magnified, rather than dampened the problem, because reserves had been minimized and so much "leverage" was used to increase returns. The rush to find safe assets and rebuild reserves reduced the values of stocks and low-grade bonds and increased those of most government securities.

A large fraction of capital reserves, and thereby sources of and access to short- and longterm financing, had disappeared. These price adjustments in the financial sector had major economic and political consequences - the latter, in part, for Olsonian (1965) reasons.

\subsection{Regulatory agencies also mistook crisis insurance for ordinary insurance}

The same neglect of outliers that characterized private market decisions also characterized regulatory decisions. Within the U.S. bureaucracies, many were oblivious to the financial tsunami that was coming, because their data bases did not cover the affected markets in much detail. Conventional bank credit continued to expand throughout 2008 (year to year and month to month). Credit flows in the new securitized debt markets, however, were not tracked in published monetary statistics. Most transactions in that market were unregulated and many of the financial products were not traded on open exchanges. They were often one-off transactions between a large buyer and large seller. ${ }^{13}$

\footnotetext{
${ }^{11}$ The St. Louis Fed's “The Financial Crisis, A Timeline of Events and Policy Actions" provides a list of significant bankruptcies during 2007-08. It also includes a long list of policies adopted by the Federal Reserve in response to recessionary pressures and problems in the non-bank portion of the financial market.

${ }^{12}$ Debt and deficit numbers vary somewhat by source, according to whether the numbers reported are fiscal year, end of year, or beginning of year, and whether one includes debt held by the Federal Reserve as publicly held or not. The Federal Reserve held an additional $\$ 800$ billion of "publically held" debt in 2007. Including the Fed's holding, the 2007 publicly held debt was $\$ 5.035$ trillion and total debt was $\$ 8.95$ trillion. Most of the non-publically held debt is held by the social security trust fund. See the Statistical Abstract of the United States 2012 table 470. (The numbers are from the Office of Management and Budget.)

${ }^{13}$ Research at the Minnesota Federal Reserve demonstrates that bank credit of all kinds expanded through mid-October 2008 (Chari et al. 2008). Other major sources of credit, however, had evidently dried up (those
} 
Many of the regulators charged with regulating various securities markets had world views that were grounded in (perfectly) efficient markets theory. They evidently believed that the "ripple on top," was simply a slightly larger than normal adjustment to new information that would soon equilibrate. The interaction of well-informed investors in competitive markets should, at least in theory, have made major price adjustments impossible. A widely held belief among regulators, economists, and financial experts was that the highly leveraged and intertwined nature of contemporary financial markets would function as normal insurance does and dampen rather than amplify economic shocks-both small and large.

However, the reserves necessary to provide crisis insurance have to be very large, and the financial crisis caused existing reserves to be rapidly drawn down. ${ }^{14}$

A subset of regulators with close connections to the financial world were aware that the financial problems were unusual and large, because they knew more about the new financial products, the extent of leverage, and the lack of truly safe capital reserves. Indeed, in a few cases, government policymakers had, themselves, been major players in the new financial markets. Nonetheless, there was little that informed policymakers could do to restrain the tidal wave they feared would be coming, beyond taking on the mantle of middlemen and encouraging mergers and spinoffs during 2007 and most of 2008 (Paulson 2010).

It bears noting that the financial firms that failed in 2007-08 were unusually large, in part, because of changes in U.S. bank regulations during the previous two decades. These changes allowed a great deal of inter- and intra-state mergers to take place and also facilitated the internationalization of finance. During the previous U.S. housing crisis in the late 1980s and early 1990s, there were many more bankruptcies, but of smaller firms. About 750 savings and loan banks failed during the late 1980s, with $\$ 400$ billion of "book" assets.

That smaller financial crisis also called forth a large infusion of crisis insurance. The assets of the failed S\&Ls were purchased by U.S. Government agencies (chiefly by the Resolution Trust Corporation, created for that purpose). As those assets were resold, the market value of the loans of the bankrupt S\&Ls turned out to be about $25 \%$ less than their book value. In the end, taxpayers paid about $\$ 90$ billion more for those mortgages than they recovered by selling them. ${ }^{15}$ The $\$ 400$ billion fund used to restore the S\&L financial subsector had been the largest "bailout" in U.S. history, although that distinction ended in 2008 .

\section{New crisis insurance programs for purchasers of mortgage-backed securities and other financial risk takers}

Many of the persons and firms affected by the 2008 financial crisis were already insured by federal programs, as with bank accounts (FDIC) and pension plans (Pension Benefit Guarantee Company [PBGC]), but many others would soon be protected by new ex-post

\footnotetext{
based on mortgage backed securities and corporate bond markets). Demand for bank credit thus naturally increased because of the decline in the credit available from the other two sources.

${ }^{14}$ The idea that an unexpected shock can overwhelm private buffer stocks and thereby affect a nation's economy is not entirely new. See, for example, Leijonhufvud (1973). The above analysis of rainy day funds suggests that such events are inevitable unless downside risks can be limited. Reinhart and Rogoff (2009) provide evidence that major financial crises occur routinely, but at irregular intervals.

${ }^{15}$ See the General Accounting Office's (GAO's) audit of the Resolution Trust Corporation (www.gao.gov/ archive/1996/ai96123.pdf).
} 
crisis insurance programs (e.g. bailouts). The policies of greatest interest for the present paper were driven by both microeconomic and macroeconomic considerations. As in many other crisis situations, the main microeconomic policy response to the financial meltdown was the creation of a variety of new safety-net programs. What is unusual in the 2008-11 case is the extraordinary size and scope of the new and extended programs, only a small subset of which have received significant press attention.

Many of the new safety net programs required new legislation. Others required significant reinterpretations of existing laws.

\subsection{Lobbying for new safety net programs: great depression warnings are sounded in Congress}

In the United States, new legislation requires persuading a majority of the members of Congress that specific new programs or modifications of existing programs are necessary for the good of the country, will improve their election prospects, or both. Such persuasive campaigns (lobbying) may be done in public through public testimony and mass media informational campaigns or in private meetings of various kinds. Both channels were used during the crisis, and together they were successful at inducing Congress and the regulatory agencies to adopt new programs. Lobbying is, of course, a continuous process for larger firms and industry groups; however, a crisis often induces legislation and other actions that are politically impossible in ordinary times, in part because of the need for quick action.

The public campaign for expanded crisis insurance evidently began in 2008, when the terms "financial crisis," "credit meltdown," and "Great Depression," were used by those advocating new legislation to address the unusually large number of bankruptcies (and potential bankruptcies) and to prop up the portfolios of a wide range of investment banks, insurance companies, and pension funds. At the time these terms were first invoked, there was little publicly available evidence of a broad credit "meltdown," or of unusual recessionary pressures. Traditional bank credit expanded throughout 2007 and 2008, and unemployment remained at relatively low levels $(5.8 \%)$, although many financial firms were in dire straits, because their reserves and lines of credit had collapsed.

A good deal of the initial talk of "crisis" was induced by the financial sector, because many of its firms (and employees) were in a state of crisis and stood to profit if a major intervention by the Federal government could be induced. Additional "crisis chatter" was induced by the natural proclivity of the news media to use the term to expand their audience. ${ }^{16}$ In addition to representatives of large financial firms, those lobbying for the new financial safety-net programs included senior officials from the U.S. Treasury, the Securities and Exchange Commission, FDIC, and Federal Reserve Board. Public testimony at Congressional hearings was reinforced through various meetings behind closed doors, many of which included representatives of large financial firms seeking new government safety nets. ${ }^{17}$

From the perspective of macroeconomics, it can be argued that textbook Keynesian macroeconomic policies were induced by that lobbying. Expansive fiscal policies were

\footnotetext{
${ }^{16}$ The terms "financial" and "crisis" have appeared in nearly 6,000 articles in the New York Times alone since 2004 and more than 30,000 times since 1851 . Nonetheless, prior to 2008 , the term financial crisis was rarely applied to the U.S. financial system, except occasionally by persons speculating that a crisis might occur at some point in the future.

${ }^{17}$ Paulson (2010) includes numerous accounts of such lobbying.
} 
adopted in the Spring of 2008 and Spring of 2009, and unprecedented trillion-dollar-plus deficits were run from 2009-11 to increase aggregate demand. Simultaneously, the monetary base was expanded at unprecedented rates, rising from $\$ 800$ billion in 2008 to $\$ 2.7$ trillion in 2011. The Federal Reserve's discount rate was lowered to and kept at nearly zero in that period (perhaps below zero in inflation-adjusted terms). ${ }^{18}$

The focus of the analysis of this paper, however, is microeconomic, rather than macroeconomic. With the particular features of the financial crisis in mind, it can also be argued that the new fiscal and monetary policies were designed to provide new reserves and new lines of credit for a subset of firms and industries with large losses from the financial crisis. By so doing, both the scope and magnitude of federal crisis insurance were greatly expanded.

\subsection{Providing crisis insurance for insurance companies}

In response to a series of successful persuasive campaigns, several expensive pieces of legislation were enacted in 2008. The first was a Keynesian stimulus program of tax rebates, adopted on February 13, 2008, that was supposed to head off the recession. (137 million families and individuals were sent tax rebates during May of 2008.) In addition, a variety of other tax reductions were extended to firms, and loan limits for FHA loans were increased. The latter was intended to help support housing values for upper middle-class homes. President Bush's "stimulus" programs were expected to cost approximately $\$ 150$ billion according to the Congressional Budget Office's February 11, 2008 estimates.

The first new major safety-net of 2008 created taxpayer-supported guarantees for the creditors of Fannie Mae and Freddie Mac. In late July, the Housing and Economic Recovery Act of 2008 made the U.S. government's implicit guarantees for Fannie Mae and Freddie Mac more explicit. ${ }^{19}$ New lines of credit from the Treasury and the Federal Reserve would provide additional safety for persons and firms holding Fannie Mae and Freddie Mac securities. The legislation authorized the Treasury to purchase obligations of these GSEs (e.g., loan Fannie and Freddie money). The safety net for creditors was strengthened by allowing the Treasury to take over the obligations of these more or less private concerns, if bankruptcy threatened, which it did a few months later.

On September 7, 2008, both Fannie Mae and Freddie Mac were placed under the federal government's conservatorship, as these privately held GSEs were in effect (re)nationalized. ${ }^{20}$ By doing so, a large part of the financial market dealing with mortgage-backed securities, including $\$ 5$ trillion of GSE debt, was now formally guaranteed (insured) by U.S. taxpayers. (It bears noting that the total publicly held debt of the U.S. government was comparable to

\footnotetext{
${ }^{18}$ The monetary base numbers are from the seasonally adjusted Board of Governors Monetary Based series (adjusted for changes in reserve requirements), available at ALFRED, the macroeconomic data base maintained by the Federal Reserve Bank of St. Louis (http://research.stlouisfed.org/tips/alfred/).

${ }^{19}$ Congressional Budget Office estimates of the present value of the implicit taxpayer guarantees to Fannie and Freddie between 1995 and 2000 varied from $\$ 6.8$ to $\$ 15.6$ billion. The implicit backing of U.S. taxpayers allows Fannie and Freddie to borrow at lower interest rates, with estimated savings vary from $\$ 3.7$ to $\$ 10.2$ billion. Their estimated regulatory and tax advantages vary from $\$ 0.7$ to $\$ 1.2$ billion. The remainder of the implicit taxpayer subsidy was through implicit (free) insurance for the GSE issues of mortgage-backed securities (Crippen 2001b: Table 1).

${ }^{20}$ Formally, these two GSEs had been private firms since the late 1960s, although a third of their boards of directors were appointed by the president. Their stocks continued to trade on the stock exchange during the period of conservatorship, although at that point, the U.S. government became their major shareholder with warrants for $79.9 \%$ of their shares. See the Congressional Research Service Report for Congress, September 15,2008 . Their stocks were delisted from the NYSE in the summer of 2010. They continue to trade on over the counter markets at about 1 percent of their value in December of 2007. See Crippen (2001a and 2001b).
} 
that of Fannie and Freddie's debt in 2007.) In the two years after the GSEs became eligible for support, Fannie and Freddie received about $\$ 150$ billion in direct support from U.S. taxpayers. The net cost of this new "social" insurance program will not be known for some time. ${ }^{21}$

The housing and recovery act provided new protections for stockholders and especially debt holders of Fannie and Freddie, which had not been paid for before the crisis. The funds paid out would be recovered if the market value of Fannie and Freddie securities were only temporarily priced below their "true" value. The legislation also merged the various GSE regulators in HUD (Department of Housing and Urban Development) to form a new tougher regulatory authority, the Federal Housing Finance Agency. The subsequent increase in Fannie and Freddie's capital reserve standards were instances of closing the barn door after the horse had left, as the capital bases of both firms had already been hollowed out by purchases of very risky mortgages at the same time that their liabilities had been increased by insuring the MBSs based on them.

Because Fannie Mae and Freddie Mac directly or indirectly insured more than half of the market for mortgage-backed securities, about half of all investors in those securities were now formally guaranteed (insured) by the U.S. taxpayers. Without this new insurance, many financial institutions would have been bankrupt, with assets valued below their liabilities, rather than illiquid. However, the mortgage-backed securities issued by other firms were not yet supported, although an $\$ 85$ billion loan was provided by the Federal Reserve to American International Group (AIG) on September 16, a major private insurer of mortgagebacked securities and other similar securitized-debt instruments.

\subsection{Crisis insurance for large banks and "important" financial institutions}

On September 19, 2008, Treasury Secretary Paulson began an intense effort (with warnings of a looming Great Depression) to persuade Congress to provide $\$ 700$ billion to purchase other mortgage-backed securities (the so-called "troubled" or "toxic" asset relief plan [TARP]). Assets, of course, are inanimate objects and require no relief. It is their owners that were to be protected from their downside risks. Paulson proposed "restarting" the market for mortgage-backed securities and other similar assets by adding a new major purchaser for those securities, namely the federal government. The original Paulson proposal was sent to Congress at midnight on September 19. It was a "back of the envelop" idea, only three pages long, that requested a $\$ 700$ billion line of credit for Treasury to use as it saw fit to purchase "troubled securities." Paulson and his advisors believed that $\$ 700$ billion was the largest amount that could be obtained from Congress (Paulson 2010: 262-67).

No other number was entertained. Paulson used his authority as Secretary of the Treasury and reputation as a financial genius at Goldman Sachs to focus attention on a single, large, rescue program, which would purchase mortgage-backed (and similar) securities, whose complexity, it was argued, had made them more difficult to price in the new riskier environment and had induced an unreasonable sell off (panic). That no other number was considered was part of Paulson's strategy for getting his proposal adopted quickly. In his words:

We needed to sell TARP hard. As Treasury staff negotiated with Congressional Democrats on the particulars, we felt we could not show any doubts about our ap-

\footnotetext{
${ }^{21}$ See the Federal Housing Finance Agency's press release of October 21, 2010, http://www.fhfa.gov/ webfiles/19409/Projections_102110.pdf. The report suggests that between $\$ 70$ billion and \$220 billion of additional support is likely to be necessary.
} 
proach or any openness to other ideas. Whenever anyone on the Hill asked the Treasury team if they had any other plans, the response was: "This is the plan." (Paulson 2010: 280)

The magnitude of the proposed financial support program was equal to about $10 \%$ of the (pre-collapse) market for mortgage-backed securities and about $20 \%$ of that not already supported through the nationalization of Fannie Mae and Freddie Mac. The amount was large enough to make a difference in a very large financial submarket.

The proposal was very large even for the U.S. government. It required a $25 \%$ increase in the Federal budget and a significant increase in national debt ceilings. The total U.S. national debt in 2008 was approximately $\$ 9$ trillion, so the Paulson plan required about an $8 \%$ increase in the total debt of the United States (about half of which is held internally, mostly by the Social Security Administration's trust fund). This would require an extraordinary issue of new Treasury bonds. The deficit in the previous year (2007) was about $\$ 161$ billion, down from about $\$ 412$ billion in 2004 . Given the size of the proposal and the urgency of the case presented, it immediately attracted enormous press attention, while other major steps taken by the Federal Reserve, Treasury, and FDIC faded into the background.

As usual, the most persuasive case for large new programs was based on public goods arguments and emergency needs. A "crisis," essentially by definition, requires rapid policy changes without significant deliberation or analysis (Congleton 2005). TARP, as discussed in Congressional hearings, was to be a new government safety net for investors in mortgagebacked securities analogous to farm price supports or the Resolution Trust Corporation used to address the S\&L crisis of the early 1990s, but on a far larger scale. TARP would provide funds to purchase mortgage-backed securities at above-market prices and thereby limit the losses of those currently holding mortgage-backed securities and others holding securities directly or indirectly supported by them. TARP, it was argued, was necessary to head off a new Great Depression.

Naturally, the Congress was initially skeptical of the proposal, although after 10 days of testimony, debate, a decline in the stock market, and the addition of a variety of amendments, both chambers of Congress deferred to Treasury's expertise on the matter. ${ }^{22}$

Given the congressional hearings and testimony by Treasury Secretary Paulson, one might have expected large-scale purchases of non-GSE issues of mortgage-backed securities to have begun almost immediately, with the Treasury paying well-above market prices. Instead, the government announced that it would purchase preferred shares from financial institutions that ordinarily could not borrow money from the Federal Reserve system. The Treasury insisted on relatively high dividends, which induced firms to buy back their preferred shares as soon as conventional sources of reserves became available. However, the preferred shares were not priced to account for differences in risk, so an implicit subsidy to

\footnotetext{
${ }^{22}$ During the first round of negotiations, the House of Representatives added a variety of oversight provisions, added a new self-financing mortgage insurance program (insisted on by a number of House Republicans), and provided for a temporary increase in the accounts eligible for FDIC insurance (from $\$ 100,000$ to $\$ 250,000$ ). The bill also reduced by half the resources immediately available to the Treasury and included provisions for resources to be used to "keep persons in their houses," where possible, and for the purchase of preferred shares-an option discussed only in passing in Congressional hearings. It also granted the SEC permission to suspend the mark-to-market accounting rules that applied to financial firms. The now 110-page document, however, was voted down in the House on September 29 (205 to 228). The 450-page bill that passed was devised in the Senate. It included a variety of "sweeteners," including revisions of the alternative minimum tax thresholds, adjustment to insurance law, and several very narrow tax and regulatory reforms.
} 
the worst-off financial firms occurred through those purchases. ${ }^{23}$ Nonetheless, TARP proved to be largely self-financing, in contrast to the programs that supported Fannie and Freddie.

\section{Beyond TARP: additional "safety nets" for bank depositors, the unemployed, state governments, and holders of mortgage-backed securities}

TARP attracted widespread coverage in the media, because it was so large, and so much discussion of it took place in congressional hearings. Perhaps surprisingly, many other new (or expanded) safety net programs were just as large, but attracted much less attention.

A new president was elected on November 4, 2008 and took office on January 20, 2009. Even before taking office, President Obama's new team asked for and received the second half of the TARP program's funding, and began to lobby for a (second) major fiscal stimulus package. President Obama and his administration continued to use the terms "crisis" and "Great Depression" in their speeches to the public and in lobbying the Congress for the second stimulus bill. Much of the second stimulus bill can also be regarded as crisis insurance.

That we are in the midst of crisis is now well understood. Our nation is at war against a far-reaching network of violence and hatred. Our economy is badly weakened, a consequence of greed and irresponsibility on the part of some but also our collective failure to make hard choices and prepare the nation for a new age. Homes have been lost, jobs shed, businesses shuttered. Our health care is too costly, our schools fail too many, and each day brings further evidence that the ways we use energy strengthen our adversaries and threaten our planet.

These are the indicators of crisis, subject to data and statistics. Less measurable, but no less profound, is a sapping of confidence across our land; a nagging fear that America's decline is inevitable, that the next generation must lower its sights. Today I say to you that the challenges we face are real, they are serious and they are many. (Presidential Obama's Inaugural Speech, January 20, 2009. [Bolding added by the author.])

Lobbying for the second stimulus program was similar to Paulson's effort to obtain the TARP program, with warnings of a Great Depression again used to motivate quick action. (Such crisis arguments were being used at the same time that many in the administration and in the Federal Reserve were predicting 3\% growth in the fourth quarter of 2009.) The new Congress again responded quickly to warnings of a pending crisis and adopted the "American Recovery and Reinvestment Act" a few weeks later, on February 13, 2009.

Together the TARP legislation and stimulus bill expanded government spending by approximately $50 \%$ over 2007 levels. Deficit finance increased to levels not seen since World War II, with budget deficits of $\$ 1.4$ trillion for 2009, \$1.3 trillion for 2010, and \$1.6 trillion for 2011.

\subsection{The U.S. Congress adopts new and extends old safety net programs}

The stimulus bill called for a variety of new programs and tax reductions totaling approximately $\$ 787$ billion, which required another significant increase in the government's debt

\footnotetext{
${ }^{23}$ Elizabeth Warren, chairman of the TARP oversight panel, testified on February 5, 2009 that the government paid $\$ 250$ billion for $\$ 176$ billion of assets (the preferred shares); the latter was an estimated value of the preferred shares, taking account of the risk of bankruptcy at that time.
} 
ceiling and another large sale of U.S. government bonds. From the Keynesian perspective, it does not matter very much how the money is spent, and much of the new spending was targeted at programs that President Obama had promised to support during his campaign for office in 2008. Much of the rest was a combination of tax reductions (for those earning less than $\$ 125,000$ per year and for small business owners) and grants to state and local governments.

Many of these programs could be regarded as new or expanded safety nets. For example, about $\$ 200$ billion of the stimulus package were grants to state governments of one kind or another. ${ }^{24}$ This represented a roughly $50 \%$ increase in central government support for state governments. (Federal grants to states in 2008 totaled $\$ 461$ billion, and accounted for approximately $27 \%$ of state expenditures.) Most states faced balanced budget constraints that would have forced them to address revenue shortfalls, which normally would have been resolved by drawing down state rainy day funds, reductions in services, and increases in state taxes. Providing new or extended support for states, in effect, allowed states to circumvent their balanced budget constraints and indirectly provided new "rainy day" funds for states. The funds used to do so, of course, were borrowed by the federal government, which does not face similar fiscal constraints.

In addition to the stimulus bill, the Congress extended unemployment benefits and created new lines of credit. During normal times, the states fund approximately 26 weeks of unemployment insurance with funds raised by earmarked taxes that are kept in trust funds administered by the federal government. During recessions, the Federal Government usually provides and pays for extended benefits. In this case, unemployment benefits were extended for an unusually long period, an additional 73 weeks.

Similarly, ordinary losses associated with bank insolvency are covered by the FDIC through insurance that is funded with fees paid by member banks. As troubled banks multiplied and deposit insurance coverage was extended, the FDIC's reserves approached zero. New reserves for this insurance program were provided by Congress through a line of credit to the Treasury that provided up to $\$ 500$ billion for FDIC actions. It is not clear at this point whether the new reserves will be paid for by banks and their depositors with new fees, or by taxpayers. In addition, Fannie and Freddie's initial U.S. Treasury lines of credit were extended and their bounds essentially removed.

All of these crisis insurance programs were funded, or to be funded, by sales of federal debt on international bond markets.

5.2 The Fed's new safety nets: over-the-counter purchases of mortgage-backed securities and other relatively risky securities

That bank credit did not collapse as other sources of credit did is largely because the Federal Reserve provided new reserves to their normal part of the banking system. By serving as the lender of last resort, these new reserves allowed banks to continue servicing credit cards, car loans, small business loans, and so forth, even if they held mortgage-backed securities on their balance sheets. Indeed, several financial firms-Goldman Sachs, Morgan Stanley, American Express, etc.- - formally became banks in order to gain access to the usual Federal Reserve services. The monetary base grew very rapidly during this period.

\footnotetext{
${ }^{24}$ The Wall Street Journal (February 17, 2009) published a fairly detailed estimate of expenditures by category. The $\$ 200$ billion estimate is calculated by adding up the grants that are either explicitly directed to states, as with $\$ 40.6$ billion for education budgets and $\$ 90$ billion for Medicaid spending. This total also includes programs that are likely to be administered by states or to substitute for state programs, as with $\$ 29$ billion for highway improvements.
} 
Several new safety nets programs were also implemented during $2008-10$ by the Federal Reserve under Section 13(3) of the Federal Reserve Act, which allows the reserve banks to extend credit to individuals, partnerships, and corporations during financial emergencies. Many of the new loan programs were consistent with the reserve's role as "lender of last resort," the last and largest shared reserve in the banking system, but the range of financial firms protected expanded significantly. Most of the new programs could be regarded as new or extended crisis insurance programs.

The new Fed programs provided safety nets for a broad cross-section of previously uninsured financial corporations. The extent of these programs (loan facilities etc.) is somewhat difficult to assess, because many of them were intertwined and interdependent. Both the Fed and Treasury were involved in providing safety nets (formally loans) for Fannie Mae, Freddie Mac, AIG, and other major financial firms, and some of the terms were renegotiated through time. A complete list of the various Federal Reserve programs with links to spreadsheets listing transactions is available from the Fed's Internet site. ${ }^{25}$

The first such program began at about the same time that the Bush stimulus bill was being negotiated in Congress. In March 2008, the Fed created a major asset-swap program (TSLF, Term Securities Lending Facility), which loaned Treasury securities to financial firms in exchange for more risky, less liquid assets held by those firms (for a monthly interest charge). TSLF thus increased the risk- and liquidity-adjusted reserves of participating financial firms by shifting illiquid assets on participant balance sheets to the Fed's balance sheet. Some $\$ 250$ billion of asset swaps were made in the first month of the program. More than $\$ 2$ trillion of asset swaps (short-term loans) were made under this program through July 2009. Among the firms taking advantage of this program were BNP Paribas, Morgan Stanley, Merrill Lynch, Goldman Sachs, Deutsche Bank Securities, Bank of America, Countrywide, Lehman Brothers, Barclays, and Credit Suisse.

In September of 2008, the Fed began implicitly guaranteeing the liquidity of previously uninsured money market funds making short-term loans through its new AMLF facility. ${ }^{26}$ This program initially demanded relatively high interest rates $(2.25 \%)$ and so only the least liquid firms participated (among which the Dreyfus money market funds are very evident).

The Fed's largest program purchased and held mortgage-backed securities previously issued by the GSEs. As noted above, the TARP program was not actually used to purchase the troubled assets most discussed during congressional hearings (mortgage-backed securities). Instead most of the money was used to provide new reserves for banks and other financial firms through the purchase of preferred stock. Shortly after the TARP funding was redirected, the Federal Reserve announced on November 25, 2008 that it would begin its own major TARP program in 2009. Its program grew to be about $75 \%$ larger than the plan proposed to Congress by Secretary Paulson. ${ }^{27}$

During the first two days of the program in January 2009, the Fed purchased about $\$ 70$ billion of mortgage-backed securities from Morgan Stanley, Barclays, Merrill Lynch, Citigroup, Goldman Sachs, BNP Paribus, Credit Suisse, and Deutsche Bank, many of which were also receiving TARP provided capital and had previously participated in the TSLF

\footnotetext{
${ }^{25}$ See: http://www.federalreserve.gov/newsevents/reform_transaction.htm.

${ }^{26}$ AMLF is a composite abbreviation of ABCP (Asset-Backed Commercial Paper), MMMF (Money Market Mutual Fund), and LF (Liquidity Facility). It operated from September 22, 2008 until February 1, 2010.

${ }^{27}$ The November 25, 2008 press release is available at: http://www.federalreserve.gov/newsevents/press/ monetary/20081125b.htm. A detailed list of purchases and sales was released on December 1, 2010.
} 
program. Between January 5, 2009 and March 31, 2010, the Fed purchased \$1.25 trillion of mortgage-backed securities created by Fannie Mae, Freddie Mac, and other GSEs. ${ }^{28}$

The Fed's purchases of MBSs modestly lifted prices for those assets, which in effect provided additional insurance for holders of MBSs and other investors in derivatives based on them. Driving the prices of MBSs up also improved the balance sheets of a wide variety of banks, investment banks, insurance companies, pension plans, and national governments, all of which had (and have) substantial holdings in mortgage-backed securities. ${ }^{29}$

It bears noting that the Federal Reserve System is itself a self-financing GSE and that its decisions to hold financial instruments in its accounts are made with considerable prudence. The MBS portfolio assembled by the Fed is as safe for the reserve banks as their usual holdings of Treasury bonds, because interest and principal payments for their MBS securities purchased are guaranteed by U.S. taxpayers, in much the same manner that interest payments for Treasury bonds are. Fannie Mae and Freddie Mac remain in conservatorship and have essentially unlimited lines of credit from the U.S. Treasury. By expanding mortgage resale markets, the Fed's program also tended to lower mortgage interest rates, which encouraged refinancing by persons with significant equity in their homes and somewhat unbundled existing MBS securities.

In addition to the Federal Reserve Bank of New York's own TARP program, the Fed also provided collateralized loans to Bears Sterns, JP Morgan, and AIG through its so-called Maiden Lane transactions. These provided approximately $\$ 75$ billion of financing to those firms at rates below those that would have been available through ordinary financial markets (if such loans could have been arranged at all). ${ }^{30}$ The loans were used to "pay any amounts owed to derivative counter parties under the related derivative contracts," and so were, in effect, an insurance fund for derivative counterparties at these three institutions.

Table 1 provides a conservative accounting of the amounts invested in the Congress' and Fed's new and/or expanded safety net programs. (The amounts insured by some of the programs and many of the program cash flows were much larger than those included in the table, as with the Fannie and Freddie obligations and the TSLF program.)

That safety net programs were provided after a financial crisis is not unusual. What is unusual is the extraordinary magnitude of these programs. The resources committed to new or extended safety nets in 2008-10 were more than eight times larger than those devoted to the S\&L program, totaling approximately $\$ 3.3$ trillion, and the implicit subsidies are also larger. To put these conservative numbers in perspective, recall that the entire federal budget was about $\$ 2.7$ trillion in 2007 and that the total publicly held debt of the federal government was $\$ 4.25$ trillion (excluding internal governmental reserve funds and holdings of the Federal Reserve) before the crisis began. ${ }^{31}$

\footnotetext{
${ }^{28}$ See the FMOC's 2010 report on Domestic Open Market Operations During 2009 and the Federal Reserve Bank of New York's FAQ on the MBS Purchase Program (August 20, 2010). Two hundred billion dollars of GSE debt were also purchased. Also, see the October 4, 2010 speech of Brian Sack, Executive Vice President of the Federal Reserve Bank of NY, http://www.newyorkfed.org/newsevents/speeches/2010/sac101004.html.

${ }^{29}$ Revisions in the mark-to-market rules used to assess the balance sheets of financial institutions also increased the value of those assets during roughly the same period, by allowing book value to be used for more assets, so the Fed's balance sheet effects are not completely obvious.

${ }^{30}$ The Maiden Lane transactions are described at http://www.ny.frb.org/markets/maidenlane.html.

${ }^{31}$ The Fed initially reduced its holding of Treasury debt but repurchased and expanded its holdings during the course of the year. See the FMOC's 2010 report on Domestic Open Market Operations During 2009, page 10.
} 
Table 1 Partial list of new or extended safety net programs 2008-10*

\begin{tabular}{lll}
\hline Date & Safety Net & $\begin{array}{l}\text { Funds Loaned or Paid } \\
\text { (billions) }\end{array}$ \\
\hline March 2008 & Maiden Lane 1 (F) & $\$ 28$ \\
March 2008 & Asset-Swaps for Financial Firms (TSLF) (F)** & $\$ 250$ \\
July 2008 & New Lines of Credit for Fannie and Freddie (C) & $\$ 150$ \\
September 2008 & Support for Money Funds (AMLF) (F)** & $\$ 170$ \\
October 2008 & TARP (C) & $\$ 700$ \\
November 2008 & Federal Reserve Announces Its TARP (F) & $\$ 500$ \\
November 2008 & Maiden Lane 2 (F) & $\$ 22$ \\
November 2008 & Maiden Lane 3 (F) & $\$ 30$ \\
February 2009 & Second Stimulus Bill's Safety Nets (C) & $\$ 200$ \\
March 2009 & Federal Reserve Expands its Tarp Program (F) \\
May 2009 & FDIC Receives Extended Line of Credit (C) & $\$ 725$ \\
$2008-10$ & Extended Unemployment Benefits (C) & $\$ 500$ \\
& Total
\end{tabular}

\section{On the demand for, and limits of, government-provided crisis insurance}

In the case of financial markets there is historical evidence that unregulated insurance companies and other financial firms tend to hold reserves below those necessary to meet their obligations during times of crisis (Meier 1988). In a few cases, this is simply fraudulent behavior, as true of the famous Madoff investment scam of the late twentieth and early twentyfirst centuries and the Ponzi schemes of the early twentieth century. In most cases, however, the under-holding of reserves may be regarded as products of optimism and perfectly legal forms of economic opportunism. Optimists will take on more debt and have higher rates of return during good times than more prudent investors, because they hold lower reserves (on which lower rates of return are earned). Opportunists, unlike optimists, may expect the good times to end at any time, but expect to gain sufficient income during the good times to carry them through the bad times, even if their companies fail. Both optimists and opportunists can offer terms in the short run that more prudent firms cannot. The success of these business models simply requires the money flowing into their reserves to exceed that flowing out during the period of interest. As a consequence, decade-long "good periods" can push prudent firms out of markets, leaving only firms that cannot survive decade-long "bad periods."

It is partly for this reason that insurance companies have been regulated (at the state level) since the middle of the nineteenth century (Meier 1988: 53). Governments that recognize recurring problems are in position to reduce the likelihood of such problems through rules that reduce risks and increase reserves, as with electrical codes and requirements that banks and insurance companies hold larger reserves than their managers believe to be adequate.

6.1 Under-funding crisis insurance programs: rosy scenarios, electoral bias, and the impossibility of maintaining large reserves

Unfortunately, government insurance programs may also underprice risk and governments may also hold inadequate reserves. Voters, like shareholders, are inclined to reward optimistic politicians with their votes, because such politicians can provide fiscal packages that 
are, or at least appear to be, more attractive than those proposed by their more prudent rivals. In good times, such politicians - as also true of optimistic investment bankers - can actually "deliver the bacon," because insurance payouts and other losses are relatively low during such periods. This rosy-scenario bias is limited by the subset of voters who are reasonably well informed, but only if they are sufficient in numbers to induce politicians to assess the risks properly. Several public choice models suggest that informed voters are often decisive (Grofman et al. 1983, Congleton 2001, 2007). In such cases, there will be significant political pressure to hold appropriate reserves to meet future insurance obligations.

Even if rosy-scenario bias is avoided, government provided crisis insurance is likely to be under-funded, because it is difficult to create adequate reserves for major crisis insurance programs. There are several reasons for this. First, crisis insurance by its nature insures risks that are often larger than anticipated by even well-informed persons. Second, the politics of collecting fees from the beneficiaries of crisis insurance tends to suffer from Olson's dilemma. The interests advanced by those programs tend to be more intense and better organized than those who may be taxed to provide subsidies for them, which tends to reinforce tendencies to underfund such programs and underprice risk.

Third, and perhaps more important for large crisis insurance programs such as those recently adopted, it is difficult to prefund such programs, because it is nearly impossible for national governments to hold large reserves that really matter. Most assets that can be used for reserves are risky, and their values are often correlated with asset bubbles and business cycles. Recall that Freddie, Fannie, and AIG all had significant capital reserves before the meltdown occurred, but their reserves evaporated as financial asset prices fell, leaving them without useable reserves when they needed them. Such problems can be avoided, of course, by holding only very safe assets in reserve such as U.S. Treasury or Swiss bonds, although holding such bonds tends to reduce the income generated by one's reserves during normal times. During times of stress, however, the demand for such safe assets normally increases, which increases both their value and liquidity.

However, when a national government agency holds large reserves of its own bonds, there is little, if any, difference between having a large reserve and selling it as needed, and having no reserves and issuing completely new bonds for sale in the world bond market as needed. To see this, consider the bonds held by the Social Security System's trust funds. In the absence of those reserves, when cash-flow problems emerge, the government would have to raise taxes or increase borrowing to meet its promises to retired persons. With the reserves, the Social Security Administration simply redeems its bonds at the U.S. Treasury, which then has to either raise taxes or increase borrowing to meet its financial obligations.

The fact that large reserves are accumulated or not by the Social Security Administration has no effect on the steps that need to be taken by Treasury and Congress, except insofar as debt ceilings may or may not have to be raised to issue new debt. The same is also true of very large crisis insurance funds. It is actually impossible to fully fund very large safetynet programs ex-ante, whether they are standard income-security programs or large crisis insurance programs.

\subsection{Ex-post funding for ex-post crisis insurance}

The fact that large crisis insurance programs cannot hold adequate reserves does not necessarily imply that moral hazard problems cannot be avoided. To reduce moral hazard and also incentives to lobby for taxpayer-subsidized insurance, crisis insurance should be properly priced for those benefiting from it-although in this case, after the fact, rather than before the fact as with normal insurance. 
Earmarked taxes and fees cannot be used to create very large reserves, but taxes and fees can be collected after a program is expanded or initiated. Insurance payouts can also be extended as loans, rather than as cash. In such cases, only those harmed by the crisis receive the benefit and only those (potentially) eligible for the benefits pay for them. Many of the recent crisis insurance programs took this form and so have been largely self-financing. For example, the Federal Reserve's safety net programs were essentially all loans of one kind or another and so far have largely been self-funding at the level of the Fed's balance sheet.

Similarly, one can imagine that special-purpose bonds could be issued to pay for crisis insurance that are to be financed via earmarked excise tax payments or ex-post insurance fees on the industries that benefit from them. The anticipation of such taxes will, of course, discourage risk taking and also lobbying for such programs, but this is entirely appropriate. All insurance fees have this effect on risk takers when they are properly priced. The point here is that ex-post funding of crisis insurance programs can reduce moral hazards, just as ex-ante funding can, and programs that are financed through new special fees and special purpose loans do so far better than programs financed from general revenues.

Ex-post earmarked taxes and insurance fees also reduce the temptation that politicians have to lower taxes by "borrowing" from trust funds, because only relatively small trust funds need be created. Although large reserves are difficult to assemble, it is relatively easy to create small reserves for pay-as-you-go programs. A standing policy under which the industries that benefit from insurance payouts have to fully fund those programs after the fact, also reduces the ability of future politicians to under-price crisis insurance in response to lobbying efforts by their supporters.

Overall, it appears that most of the new crisis insurance programs of 2008-11 were designed with moral hazard problems in mind. In several cases, however, no provisions were made to assure that those receiving insurance payouts or new lines of credit would pay them back, as for example with tax-financed funds for Fannie Mae and Freddie Mac. Similarly, many of the new safety net programs of the 2009 stimulus bill were funded from general revenues, as with inter-governmental grants and extended unemployment insurance. In principle, to avoid moral hazard problems these expenditures should be paid back over time through ex-post fees paid by mortgage-backed security owners and through temporary state tax surcharges.

Taxpayer subsidies and below-market interest rates on loans encourage risky behavior and smaller than prudent private reserves, and thereby make future fiscal crises more likely. Subsidized programs also encourage rent seeking in a manner that formal, self-financing, programs do not.

\subsection{The fiscal limits of debt-financed crisis insurance}

In the absence of a fully funded insurance reserve fund, the upper bound on public crisis insurance programs is determined by a government's borrowing capacity, which is determined by the strength of its economy, its citizenry's willingness to pay taxes, and its macroeconomic policies (expected inflation rate). Fully exploiting that capacity tends to produce additional risks for reasons similar to those associated with private leverage, even when most of the loans are paid off through earmarked fees and taxes paid by program beneficiaries. Unpleasant surprises can exhaust both reserves and lines of credit.

Here we may note the problems that Ireland confronted in its attempt to provide crisis insurance for its banking sector. The Irish crisis insurance programs were similar to those provided by the United States and several other OECD countries, but were larger relative to Ireland's international borrowing capacity. Potential bond purchasers clearly feared that the 
new Irish debt would not be repaid, and so were not willing to buy Irish bonds at normal interest rates. A sizable risk premium was demanded, which Ireland could not afford to pay. Similar limits exist for all countries.

In the American case, borrowing $\$ 450$ billion in 2008 and more than $\$ 1$ trillion a year for several years afterwards clearly brought the United States closer to its borrowing limits. (The largest [nominal] debt issue before 2008 was $\$ 412$ billion in 2004.) The amount of debt held by the public approximately doubled between 2007 and 2011 from about $\$ 4.25$ trillion in 2007 to more than $\$ 9$ trillion in 2011 (again excluding Fed holdings). Of that new total, more than $\$ 4.5$ trillion is held abroad and much of that by foreign governments. (The three largest international holders of U.S. debt are China, Japan, and the United Kingdom, which jointly hold about $\$ 2.4$ trillion of Treasury securities. ${ }^{32}$ ) The recent bond issues are large relative to the world's government bond market. Four and a half trillion dollars of new debt issues in the past three years represents about an $8 \%$ increase in world sovereign debt, and this expansion occurred while many other countries were also attempting to borrow to provide crisis insurance. ${ }^{33}$

During fiscal crises, investors are more willing to hold sovereign debt than at other times, because it is regarded as a relatively safe asset. This increases the upper bound on the use of sovereign debt to address crises. Nonetheless, investors cannot be assumed to have a completely elastic demand for all government bonds, as evidenced by the 2011 European sovereign debt problems. Investors are naturally concerned with taxpayer ability and willingness to service their debt, in addition to international currency risks associated with trade imbalances and inflation. The experiences of Iceland, Ireland, Greece, Portugal, and Italy demonstrate that even a small risk of default can significantly affect national access to international credit, just as it can for private companies.

As more and more crisis insurance is explicitly or implicitly added to a government's core responsibilities without explicit policies to finance it through ex-post (or ex-ante) fees or taxes to beneficiaries, governments move closer to their borrowing limits. The finite size of the world's sovereign debt markets implies that there is an upper bound on the extent to which even large and historically "safe" governments can serve as the "insurers of last resort."

It would be prudent to keep such limits in mind when thinking about alternative longrun strategies for addressing future national and international crises. Just as in the case of normal insurance, it may be prudent to limit the coverage provided and attempt to make all crisis insurance programs self-financing in the long run. Without reforms that reduce future demands for crisis insurance, the next major crisis may be far worse than the present one. Crisis insurance is likely to be much more expensive, if it is available at all, as more national governments approach their tax and borrowing limits.

Acknowledgements The present paper benefited from comments made during seminars at West Virginia University and at Virginia Polytechnic Institute and State University. The comments and suggestions of the editor of this journal were especially helpful.

\footnotetext{
${ }^{32}$ See "Major Foreign Holders of Treasury Securities," Department of the Treasury/Federal Reserve Board (October 18, 2011). According to that report, China is the largest holder of Treasury securities with 1.1 Trillion dollars of holdings.

${ }^{33}$ The CIA World Factbook includes another listing of debt issues by all the governments in the world. Its tabulation is somewhat higher for the United States and world than the Treasury report used above. The CIA estimates that total world sovereign debt is approximately $\$ 60$ trillion. OECD countries top the CIA list of government debt issuers.
} 


\section{References}

Bernanke, B. S. (2008). Mortgage delinquencies and foreclosures. Speech at Columbia Business School (May 5). Available at: www.federalreserve.gov/newsevents/speech/Bernanke20080505a.htm\#f2.

Board of Governors of the Federal Reserve System (2008). Statistical Supplement to the Federal Reserve Bulletin, 5(10) (October). Washington, D.C.

Brown, M. J., \& Hoyt, R. E. (2000). The demand for flood insurance: empirical evidence. Journal of Risk and Uncertainty, 20, 291-306.

Capozza, D. R., \& Seguin, P. J. (1994). Expectations, efficiency, and euphoria in the housing market. Regional Science and Urban Economics, 26, 369-386.

Case, K. E., Quigley, J. M., \& Shiller, R. J. (2001). Comparing wealth effects: the stock market versus the housing market (Cowles Foundation Discussion Paper No 1335). New Haven: Yale University.

Cecchetti, S. G. (2008). Measuring the macroeconomic risks posed by asset price booms. In J. Y. Cambell (Ed.), Asset prices and monetary policy (pp. 9-34). Chicago: University of Chicago Press.

Chari, V. V., Christiano, L., \& Kehoe, P. J. (2008). Facts and myths about the financial crisis of 2008 (Federal Reserve Bank of Minneapolis Working Paper 666) (October). Available at: www.minneapolisfed. org/research/WP/WP666.pdf.

Congleton, R. D. (2001). Rational ignorance and rationally biased expectations: the discrete informational foundations of fiscal illusion. Public Choice, 107, 35-64.

Congleton, R. D. (2005). Toward a political economy of crisis management: rational choice, ignorance, and haste in political decision making. Dynamics of Intervention, Advances in Austrian Economics, 8, 183204.

Congleton, R. D. (2006). The story of Katrina: New Orleans and the political economy of Catastrophe. Public Choice, 127, 5-30.

Congleton, R. D. (2007). Informational limits to democratic public policy: the jury theorem, yardstick competition, and ignorance. Public Choice, 132, 333-352.

Congleton, R. D. (2009). On the political economy of the financial crisis and bailout of 2008-09. Public Choice, 140, 287-317.

Crippen, D. L. (2001a). Federal subsidies and the housing GSEs (Congressional Budget Office Report). Washington, D.C. Available at: www.cbo.gov/ftpdocs/28xx/doc2841/GSEs.pdf.

Crippen, D. L. (2001b). Federal subsidies for the housing GSEs. Testimony before the subcommittee on capital markets (May 23). U.S. House of Representatives. Available at: www.cbo.gov/doc.cfm?index= 2839\&type $=0$.

Duke, E. A. (2009). Stabilizing the housing market: next steps. February 11 speech at the Global Association of Risk Professionals' Risk Management Convention, NY. Available at: http://www.federalreserve. gov/newsevents/speech/duke20090211a.htm.

Financial Crisis Inquiry Commission (2011). The financial crisis inquiry report. Washington: Government Printing Office.

General Accounting Office (1996). Financial audit: resolution trust corporation's 1995 and 1994 financial statements. Washington, D.C. Available at: www.gao.gov/archive/1996/ai96123.pdf.

General Accounting Office (2001). Information on the financial condition of the national flood insurance program. Washington, D.C. Available at: www.gao.gov/new.items/d01992t.pdf.

Greenberg, A. C. (2010). The rise and fall of Bear Stearns. New York: Simon \& Schuster.

Grofman, B., Owen, G., \& Feld, S. (1983). Thirteen theorems in search of the truth. Theory and Decision, $15,261-278$.

Higgs, R. (1989). Crisis and leviathan: critical episode in the growth of American Government. Oxford: Oxford University Press.

Leijonhufvud, A. (1973). Effective demand failures. The Swedish Journal of Economics, 75, $27-48$.

Jenkinson, N. (2008). Ratings in structured finance: what went wrong and what can be done to address shortcomings? (CGFS Papers 32). Basel: Committee on the Global Financial System.

Kennickell, A. B. (2006). Currents and undercurrents: changes in the distribution of wealth 1989-2004 (August 2). Washington: Federal Reserve Board Report.

Knight, F. H. (1921). Risk, uncertainty, and profit. Boston: Houghton Mifflin Co.

Lei, V., Noussair, C. N., \& Plott, C. R. (2001). Nonspeculative bubbles in experimental asset markets: lack of common knowledge of rationality vs. actual irrationality. Econometrica, 69, 831-859.

Lewis, M. (2010). The big short: inside the doomsday machine. New York: Norton.

Meier, K. J. (1988). The political economy of regulation: the case of insurance. Albany: State University of New York Press.

Olson, M. (1965). Logic of collective action, public goods and the theory of groups. Cambridge: Harvard University Press.

Paulson, M. P. (2010). On the brink. New York: Hachette Book Group. 
Reinhart, C. M., \& Rogoff, K. (2009). This time is different: eight centuries of financial folly. Princeton: Princeton University Press.

Tibman, J. (2009). The murder of Lehman Brothers: an insider's look at the global meltdown. New York: Brick Tower Books.

Young, A. (2008). Replacing incomplete markets with a completeness: Katrina and the NFIP. International Journal of Social Economics, 35, 561-568. 